\title{
Earth's Future
}

\author{
RESEARCH ARTICLE \\ 10.1029/2020EF001818 \\ Key Points: \\ - We measure geometric \\ characteristics of sandy washover \\ deposits in built and unbuilt coasta \\ environments following hurricane \\ strikes \\ - We quantify systematic similarities \\ and differences between washover \\ morphology in built and unbuilt \\ environments \\ - Our findings suggest that the \\ "fabric" of the built environment \\ exerts a fundamental control on \\ large washover deposit form
}

Supporting Information:

- Supporting Information S1

Correspondence to:

E. D. Lazarus and E. B. Goldstein, E.D.Lazarus@soton.ac.uk; ebgoldst@ uncg.edu

\section{Citation:}

Lazarus, E. D., Goldstein, E. B., Taylor, L. A., \& Williams, H. E. (2021). Comparing patterns of hurricane washover into built and unbuilt environments. Earth's Future, 9, e2020EF001818. https://doi. org/10.1029/2020EF001818

Received 21 SEP 2020 Accepted 20 JAN 2021

Author Contributions:

Conceptualization: Eli D. Lazarus, Evan B. Goldstein

Data curation: Luke A. Taylor

Formal analysis: Eli D. Lazarus, Evan B. Goldstein, Luke A. Taylor, Hannah E. Williams

Funding acquisition: Eli D. Lazarus, Evan B. Goldstein

(c) 2021. The Authors.

This is an open access article under the terms of the Creative Commons Attribution-NonCommercial-NoDerivs License, which permits use and distribution in any medium, provided the original work is properly cited, the use is non-commercial and no modifications or adaptations are made.

\section{Comparing Patterns of Hurricane Washover into Built and Unbuilt Environments}

\author{
Eli D. Lazarus ${ }^{1}\left(\mathbb{D}\right.$, Evan B. Goldstein ${ }^{2}$ (D) Luke A. Taylor ${ }^{1}$, and Hannah E. Williams ${ }^{1}$ \\ ${ }^{1}$ Environmental Dynamics Lab, School of Geography and Environmental Science, University of Southampton, \\ Southampton, UK, ${ }^{2}$ Department of Geography, Environment, and Sustainability, University of North Carolina at \\ Greensboro, Greensboro, NC, USA
}

\begin{abstract}
Extreme geohazard events can change landscape morphology by redistributing huge volumes of sediment. Event-driven sediment deposition is typically studied in unbuilt settings - despite the ubiquity of occurrence and high economic cost of these geohazard impacts in built environments. Moreover, sedimentary consequences of extreme events in built settings tend to go unrecorded because they are rapidly cleared, at significant expense, from streets and roads to facilitate emergency response. Reducing disaster costs requires an ability to predict disaster impacts, which itself requires comprehensive measurement and study of the physical consequences of geohazard events. Here, using a database of poststorm aerial imagery, we measure plan-view geometric characteristics of sandy washover deposits in built and unbuilt settings following five different hurricane strikes along the Atlantic and Gulf Coasts of the US since 2011. We identify systematic similarities and differences between washover morphology in built and unbuilt environments, which we further explore with a simplified numerical model. Our findings suggest that spatial characteristics of the built environment (termed "fabric") - specifically, the built fraction of the depositional zone - exerts a fundamental control on the form of large deposits. Accounting for the influence of built fabric on the morphodynamics of flow-driven geohazards is a tractable step toward improved forecasts of hazard impacts and disaster risk reduction.
\end{abstract}

Plain-language Summary Many kinds of hazardous extreme events - floods, landslides, and volcanic activity - send flows laden with sediment coursing into built environments. For example, when hurricanes strike built-up areas of low-lying coastline, huge volumes of sand get channeled down streets and between buildings, requiring expensive emergency clean-up. Patterns of hurricane-driven deposition in the fabric of built settings have been described but rarely measured. We measure hurricane deposits in built and unbuilt environments and find systematic similarities and differences between the two types of setting. Our findings suggest that assessment and mitigation of disaster risk in built environments prone to flow-driven hazards could be improved by accounting for the effect of built fabric on sediment dynamics.

\section{Introduction}

Extreme events such as storms, floods, landslides, and volcanic eruptions can redistribute huge volumes of sediment in landscape systems. These geomorphic impacts tend to be studied in landscapes with minimal human presence, infrastructure, or intervention, to reduce confounding factors on sediment transport. However, human domination of natural environments means that unbuilt conditions now represent exceptional circumstances (Ellis \& Ramankutty, 2008; Foley et al., 2005; Halpern et al., 2015; Venter et al., 2016; Vitousek et al., 1997). Moreover, built environments are ubiquitous in hazard-prone settings world-wide. According to the global Emergency Events Database (EM-DAT), since 1970, a total of over 12,000 recorded natural disaster events have affected, on average, more than 150 million people each year - and occasionally several times that number. Economic damage from those disasters totals approximately US\$ 4.5 trillion (adjusted to 2019 US\$), or an average of nearly US\$ 91 billion annually (CRED, 2019). Reducing disaster costs requires, among other capacities, an ability to predict disaster impacts - which itself requires comprehensive measurement and study of the physical consequences of geohazard events. Buried in the global figures for disaster damage, for example, are the costs associated with removing debris from built environments - debris that can include in any given event, hundreds of thousands to tens of millions of cubic meters of 
Investigation: Eli D. Lazarus, Evan B. Goldstein, Luke A. Taylor, Hannah E. Williams

Methodology: Eli D. Lazarus, Evan B. Goldstein, Luke A. Taylor, Hannah E. Williams

Project administration: Eli D. Lazarus

Supervision: Eli D. Lazarus Writing - original draft: Eli D. Lazarus, Evan B. Goldstein, Luke A. Taylor

Writing - review \& editing: Eli D. Lazarus, Evan B. Goldstein, Luke A. Taylor, Hannah E. Williams sediment (Brown et al., 2011; Environmental Protection Agency (EPA), 2019; Federal Emergency Management Agency (FEMA), 2020; Lipton, 2013; Periathamby et al., 2012).

A growing body of research into hazard systems - specifically those that involve sediment deposition - is revealing how extreme events interact with built and unbuilt environments in fundamentally different ways. Examples of this divergence tend to be more qualitative than quantitative, but come from a diverse range of hazard types: floods (Nelson \& Leclair, 2006), coastal storms (Hall \& Halsey, 1991; Nordstrom, 2004; Rogers et al., 2015; Smallegan \& Irish, 2017), tsunamis (Bricker et al., 2015; Park et al., 2013), landslides and debris flows (Del Ventisette et al., 2012; Papathoma-Köhle et al., 2017), and volcanic eruptions - both modern (Doronzo \& Dellino, 2011) and historical (Gurioli et al., 2005,2007; Zanella et al., 2007). Systematic, quantitative comparison of event-driven deposition in built and unbuilt settings requires collating characteristics of sediment deposits across different locations, events, and hazard systems. If spatial characteristics of the built environment control the shape of washover deposits, then the same spatial characteristics likely steer or otherwise control the overwash flows that create those deposits. Synthesis of morphological characteristics in extreme-event deposits is an empirical step toward modeled prediction of impacts, understanding disaster risk, preparing for disaster response, and risk reduction in built environments prone to geomorphic hazard in alignment with key goals of the UN Sendai Framework for Disaster Risk Reduction (UN General Assembly, 2015).

Here, we quantify morphological characteristics of sediment deposits from tropical cyclone strikes along the low-lying and extensively developed Atlantic and Gulf coastlines of the US. During the past 4 decades, the intensity of tropical cyclones globally has increased (Kossin et al., 2020). In the US, since the 1970s, population has grown disproportionately in coastal counties (NOAA, 2013) and hurricane strikes have become more damaging (Grinsted et al., 2019). On sandy coastlines like the US Atlantic and Gulf, a geomorphic signature of extreme coastal storms is washover deposits - fans, or sheets of sediment transported onto the subaerial coastal plain by elevated water levels and shallow overland flow. These deposits do not only result from hurricanes - they can form with any weather event that drives a sufficiently elevated water level - but here we limited our examination to hurricanes cataloged in the bank of orthorectified poststorm aerial imagery from NOAA (National Geodetic Survey, 2020). Washover is constructional: as the main contributor to the subaerial sediment budget of low-lying coastlines, washover regulates the elevation of coastal barrier environments relative to sea level (FitzGerald et al., 2008). Most geomorphic investigations of coastal storm deposition consider unbuilt environments (Donnelly et al., 2006; Engelstad et al., 2017, 2018; Hudock et al., 2014; Lazarus, 2016; Lazarus \& Armstrong, 2015; Leatherman \& Zaremba, 1987; Masselink \& van Heteren, 2014; Matias et al., 2009; Morton \& Sallenger, 2003; Sallenger, 2000; Shaw et al., 2015; Wesselman et al., 2018). A few notable exceptions have measured washover extent (Hall \& Halsey, 1991; Morton \& Paine, 1985) and volume (Overbeck et al., 2015; Rogers et al., 2015; USGS, 2005) in beachfront built environments following a storm event, or described the phenomenon in built settings more broadly (Nordstrom, 2004). One reason for this dearth of investigations in built environments is that storm deposits in built areas are rapidly cleared away by road crews (Nelson \& Leclair, 2006; Nordstrom, 2004) - sometimes even as the storm and deposition is in progress (Lazarus \& Goldstein, 2019). Paired topographic surveys from immediately before and after every storm event would be ideal - particularly in order to measure depositional volume - but immediate prestorm topographic data is typically missing (see Sherwood et al., 2018). Even where comprehensive coastal-monitoring programs exist (as in the United States), high-resolution topographic surveys over spatially extended reaches of coastline are conducted infrequently, relative to storm incidence. As a result, poststorm imagery typically serves as the only record of deposition patterns (Figure 1). (Experimental evidence suggests that two-dimensional and three-dimensional deposit morphometry are related (Lazarus, 2016), but further work - particularly on field examples - is needed to establish empirical scaling rela-
Figure 1. Excavators (circled and detailed) clearing washover sand from the main road along Dauphin Island, Alabama, October, 10 2017, 2 days after Hurricane Nate. (Location marker $x$ : $30^{\circ} 15^{\prime} 03^{\prime \prime} \mathrm{N}, 8^{\circ} 10^{\prime} 77^{\prime \prime} \mathrm{W}$.) Image courtesy of National Oceanic and Atmospheric Administration (NOAA). 
(a) deposit types \& measurements

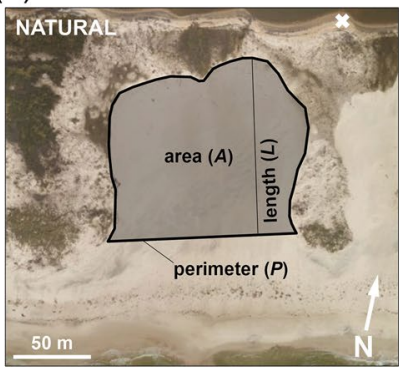

(b) site locations
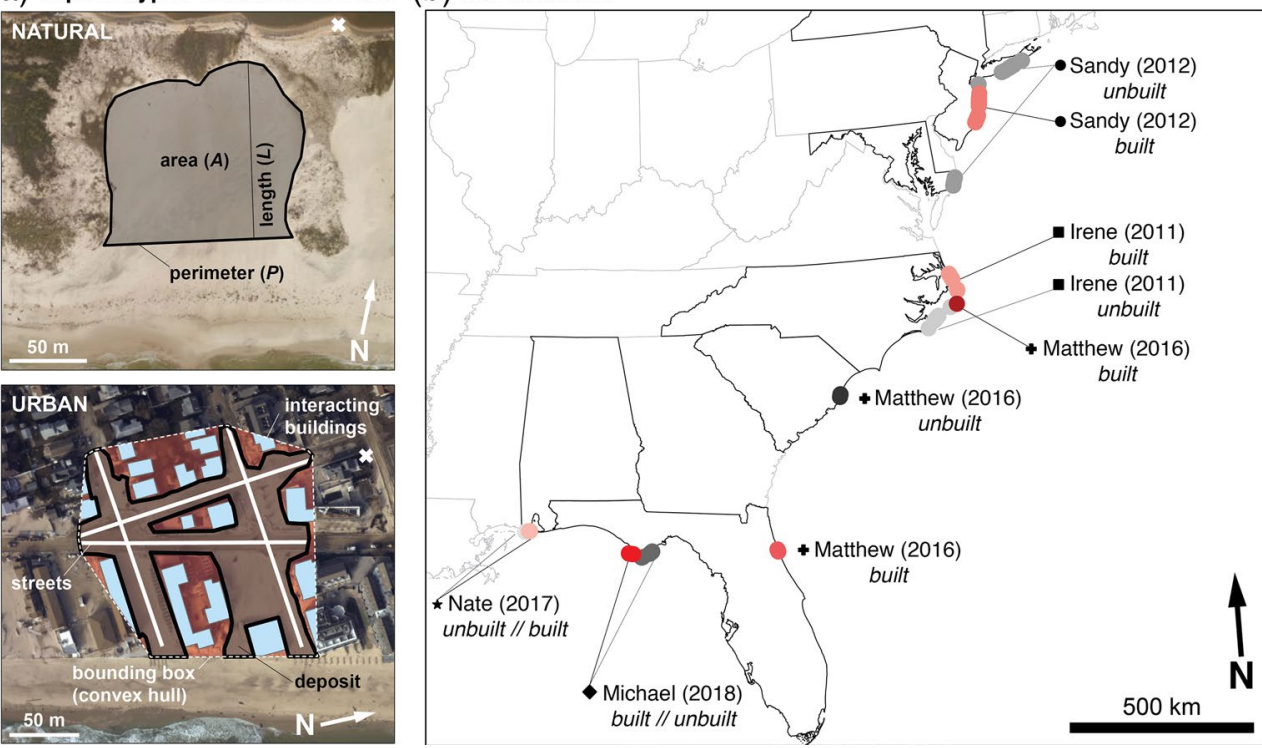

Figure 2. Hurricane deposition in comparative settings. (a) Illustrative comparison of washover in unbuilt (upper panel; location marker $x: 30^{\circ} 14^{\prime} 5^{\prime \prime} \mathrm{N}, 88^{\circ} 16^{\prime} 55^{\prime \prime} \mathrm{W}$ ) and built environments (lower panel; location marker $x: 40^{\circ} 5^{\prime} 19^{\prime \prime} \mathrm{N}$, $74^{\circ} 2^{\prime} 22^{\prime \prime} \mathrm{W}$ ), showing washover geometry and built fabric we use in this analysis. Deposit in upper panel is from Dauphin Island, Alabama, following Hurricane Nate (2017); deposit in lower panel is from Point Pleasant Beach, New Jersey, following Hurricane Sandy (2012). Images courtesy of National Oceanic and Atmospheric Administration (NOAA). (b) Map of washover sampling locations by hurricane and setting type. Shades of red indicate relative built fraction; gray dots indicate unbuilt sites, and are shaded to match the red dots with the pair. Data distributions of built fraction by location are provided in Figure S1.

tionships between, for example, deposit area and volume.) Deposits in built settings are ephemeral, yet they are fundamental to predicting impacts of future extreme storms, gaining an accurate accounting of sediment budgets in coastal built environments, and finding ways to reduce the burdensome economic costs of poststorm cleanup.

In this analysis, we measure the length, perimeter, and area of individual washover deposits in built ( $n=167)$ and unbuilt $(n=115)$ settings (Figure $2 \mathrm{a}$ ), captured by aerial imagery (National Geodetic Survey, 2020) following five different hurricane events along the Atlantic and Gulf Coasts of the US: Irene (2011), Sandy (2012), Matthew (2016), Nate (2017), and Michael (2018) (Figure 2b). We examine and compare scaling relationships in deposit geometry across both built and unbuilt settings, and explore the effect of spatial characteristics of the built environment - termed "fabric" - on washover morphology. Most of the spatial characteristics used to describe fabric come from network graph nomenclature, and are measures such as node density and connectivity, street length and density, and built area (Boeing, 2017). We focus on built fraction: the total area of building footprint within a given area, defined here by a convex-hull bounding box around a given washover deposit in a built setting. Numerical experiments from a deliberately simplified numerical model of washover align with and expand upon our empirical results.

\section{Methods}

\subsection{Empirical Measurements}

We identified washover deposits visible in geolocated, orthorectified poststorm aerial imagery from NOAA (National Geodetic Survey, 2020), captured within days of hurricane strikes on the US Atlantic and Gulf Coasts (see Table S1). Washover footprints in built and unbuilt settings were digitized manually by the same person using ArcGIS Pro. All data were projected in the NAD 83 coordinate system. Perimeter and area of each deposit footprint were calculated automatically. Length, taken as the longest orthogonal distance between the seaward and landward edges of the deposit, was determined manually using the Measure tool. In 
cases where interior portions of a deposit had already been cleared from roads, deposit extent was discerned from plowed ridges of sand evident at roadway margins.

To quantify the fabric of the built environment, building footprints were extracted from the open-access data set of US building footprints published by Microsoft (https://github.com/microsoft/USBuildingFootprints), and OpenStreetMap street networks downloaded from Geofabrik (https://download.geofabrik.de/). The JSON-to-Feature-Class tool in ArcGIS was used to convert each state-level GeoJSON file of building footprints into a usable format for ArcGIS. Convex-hull bounding boxes were applied to washover deposits in built settings to capture buildings interacting with a deposit edge, along with any buildings fully enveloped by a deposit (Figure 2a). With the Intersect tool in ArcGIS, building footprints and street networks were clipped by the convex-hull bounding boxes around each deposit to calculate the total (two-dimensional) building area and total street length present within each bounding box.

In built settings, washover perimeter was taken as the outer perimeter of a deposit, and thus excludes the perimeter of any interior geometry created by fully enveloped buildings. Deposit area excludes the area of any buildings' interior to (or otherwise interacting with) the deposit. Built fraction was calculated as the total area of building footprint within a convex-hull bounding box, divided by the area of the bounding box. Street length was calculated as the total linear length of street network within a deposit footprint.

\subsection{Numerical Model}

To systematically explore generic patterns of washover deposition into built environments, we adapted a simplified numerical model of washover deposition, described in full by Lazarus and Armstrong (2015), to include generic fabrics for a range of built fractions. (The model code, written in MATLAB, is available at https://github.com/envidynxlab/Model-World). The structure of the numerical model is cellular. One edge of the model domain (here, $100 \times 100$ cells) is an erodible barrier of height $z=1$. Initial water height on the seaward side of the barrier is set equal to barrier height. The floodplain on the landward side of the barrier is topographically flat, but built areas are added as a regular grid of nonerodible blocks of arbitrary height $z=2$ (to ensure no overtopping). Built footprints are square, and are expanded incrementally over successive trials by increasing the edge length of built squares by one cell. Streets between built squares are held to a constant width of four cells. This configuration of the built environment is not intended to simulate a particular locale, only to capture a range of built fractions. Each domain condition is trialed 25 times.

Because the barrier topography is otherwise uniform, we initiate cross-shore overwash flow and subsequent back-barrier deposition by imposing an incision, or breach, in the barrier at a given site alongshore. (This also forces the model to only generate one washover deposit per numerical trial) In each trial, overwash initiates at a different site, randomly selected from within the middle 60 cells of the barrier edge (to avoid edge effects), and with a different initial incision depth, taken as a proportion of barrier height randomly selected between 0.1 and 0.7. The initial incision site is a single model-cell wide. This is a simplifying assumption - but once initiated, incision width is allowed to adjust dynamically, as flow through the incision and lateral diffusion of the barrier crest across the incision rapidly reworks the initial shape of the imposed perturbation. Varying the depth of the initial incision produces a variety of deposit areas for a given domain and elevated water level. We do not vary storm forcing as represented by water level. Cross-shore overwash flow (from the seaward edge of the domain landward) occurs when water height exceeds barrier height. Water set-up against the barrier is treated as a conserved quantity, such that water height along the barrier is lowered at each time step by the volumetric loss from overwash discharge through the incision. Sediment from the barrier is moved as a proportion of flow depth at a given cell; we include a threshold depth required to move sediment. Flow depth at a given cell is distributed proportionally to all neighboring cells of lower elevation, leaving behind a sediment lag (as a proportion of flow depth). In this way, a washover deposit fans into the floodplain domain from the barrier. The assumptions governing the incision and its morphological evolution in detail do not make a material difference to the resulting deposit morphometry - the area of the modeled deposit is effectively determined by hydraulic head and the quantity of sediment made available for redistribution from the barrier to the back-barrier floodplain. In the field, overwash flow might widen and flatten incisions to the point of erasure, as in an inundation regime, or swash during the falling limb of the storm event might obscure or rework incision features (see discussion in Lazarus, 2016). 
Each trial runs for a fixed duration of 20 iterations. The number of iterations is nominally analogous to storm duration, but here is set for convenience: the bulk of the washover deposit forms rapidly, within a few iterations, and stops growing once overwash flow depths over its topography are too shallow to move any more sediment. Here, limiting the duration to 20 iterations also ensures that the largest deposits do not flow off the far landward edge of the domain when built fraction $=0$. The model domain is not scaled to match length scales in the empirical data (the areas of our modeled deposits are in arbitrary units).

\section{Analysis and Results}

Geomorphic scaling laws define consistent mathematical relationships between physical attributes of a landscape feature - for example, how the length of a feature changes relative to its area - and can serve as a powerful predictive tool even when the physical mechanisms that underpin a geomorphic system are incompletely understood (Dodds \& Rothman, 2000). Geomorphic scaling laws for washover deposits derive almost exclusively from unbuilt environments (Lazarus, 2016; Lazarus et al., 2020; Rogers et al., 2015). Here, we extend scaling analysis typical of unbuilt environments into built settings to examine if, and how, the resulting scaling relationships may diverge - especially given that field descriptions of washover deposits in built environments remark upon their distinctive shapes (Hall \& Halsey, 1991; Morton \& Paine, 1985; Nordstrom, 2004; Rogers et al., 2015), as they branch down streets and between buildings (Figure 2a).

Despite clear examples of visibly contrasting morphology in the poststorm imagery (Figure 2a), we find that washover in built and unbuilt settings are effectively indistinguishable in a scaling relationship between length and area, and respective distributions of $L / A$ (Figure 3a). A more sensitive metric for differentiation is deposit perimeter (Figure $3 \mathrm{~b}$ ). For a given area $A$, washover deposits in built environments exhibit longer perimeters than in unbuilt environments. (Note that the scaling laws that we report are nonlinear regressions of the form $y=C x^{h}$ performed in linear space; results are shown plotted in log space.) For large areas, the perimeter data do not collapse to a single relationship: some washover deposits from built and unbuilt settings exhibit similar morphometry, while other deposits in built settings have systematically larger perimeters (Figure 3b).

To examine structure within the relationship between perimeter and area in greater detail, we formulated a dimensionless metric we term the distortion index $(D I)$ :

$$
\mathrm{DI}=\frac{P_{\mathrm{m}}}{P_{\mathrm{i}}}
$$

which compares the measured perimeter $\left(P_{\mathrm{m}}\right)$ to the idealized perimeter of a semicircle plus its diameter $\left(P_{\mathrm{i}}\right)$ with the same area as the measured deposit:

$$
P_{\mathrm{i}}=(\pi+2) \sqrt{\frac{2 A_{\mathrm{m}}}{\pi}}
$$

The utility of this metric is that it reflects the relative complexity of deposit perimeter as a planform path, much the way rugosity compares real to projected area to reflect the relative complexity of a surface. The perimeter of any idealized geometric shape could serve in the denominator of the distortion index, but we use a semi-circular arc (plus the diameter) since it is a common depositional fan shape, found in a range of environments (Bull, 1977; Donnelly et al., 2006; Hudock et al., 2014; Lazarus, 2016; Millard et al., 2017; Moscardelli \& Wood, 2016), and washover tends toward this fan shape (e.g., Price, 1947). Changing the idealized geometric shape adjusts the range of the index, but not the qualitative pattern of the results.

Applying the distortion index to the relationship between perimeter and area reveals a gradient in deposit distortion, such that deposits in built settings with larger area tend to be more distorted than deposits with smaller area, relative to their unbuilt counterparts (Figure 3b). Spatial characteristics of the built environment, which describe the built fabric, indicate potential controls on the relationship between distortion index and area (Figure 4a; Figures S1, S4, and S5). Comprehensive analysis of built fabric in the US has shown that spatial characteristics of the built environment are heterogeneous: values of a given metric may express a narrow range, but different regions - even those broadly typified by suburban development 

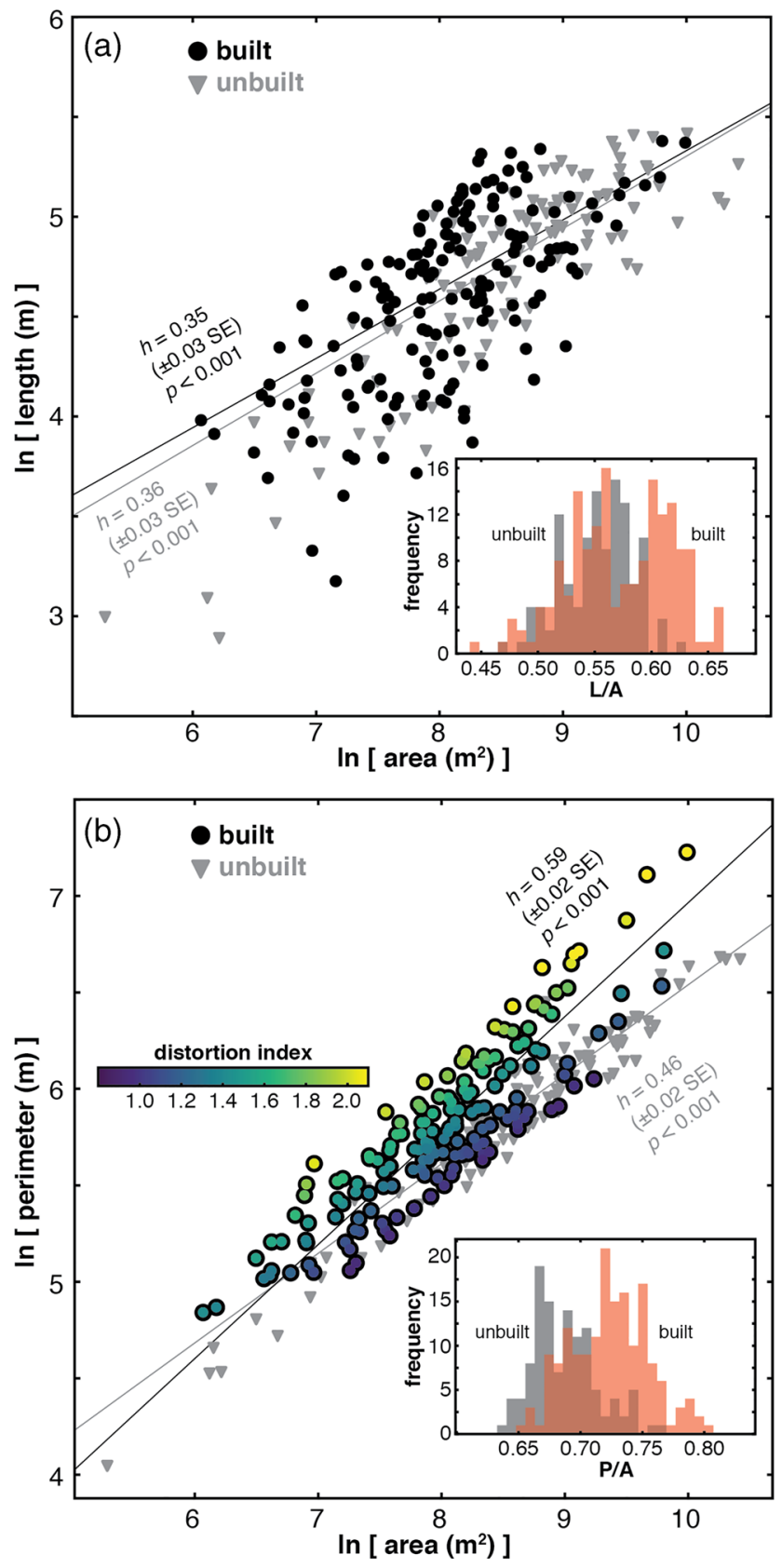

Figure 3. Scaling relationships for washover deposits in built and unbuilt settings. (a) Washover length relative to area from built (black circles) and unbuilt settings (gray triangles). Inset shows relative distributions of length-to-area ratio for the two types of setting. The closely overlapping distributions in this relationship make any morphological differences between the two settings difficult to discern. (b) Washover perimeter relative to area from built (black circles) and unbuilt settings (gray triangles); inset shows relative distributions of the perimeter-to-area ratio. This relationship shows a clearer distinction in washover morphology from the two types of setting. Color gradient superimposed on the built-setting data shows the distortion index (DI) of each data point, or the degree to which the perimeter deviates from the perimeter of an idealized semi-circle of the same area, and indicates a further dimension of organization embedded in the perimeter-to-area relationship. Nonlinear regressions of the form $y=C x^{h}$ were performed in linear space; results are plotted in log space. Summary statistics are provided in Table S1, and additional plots of comparative data distributions in Figure S2. 

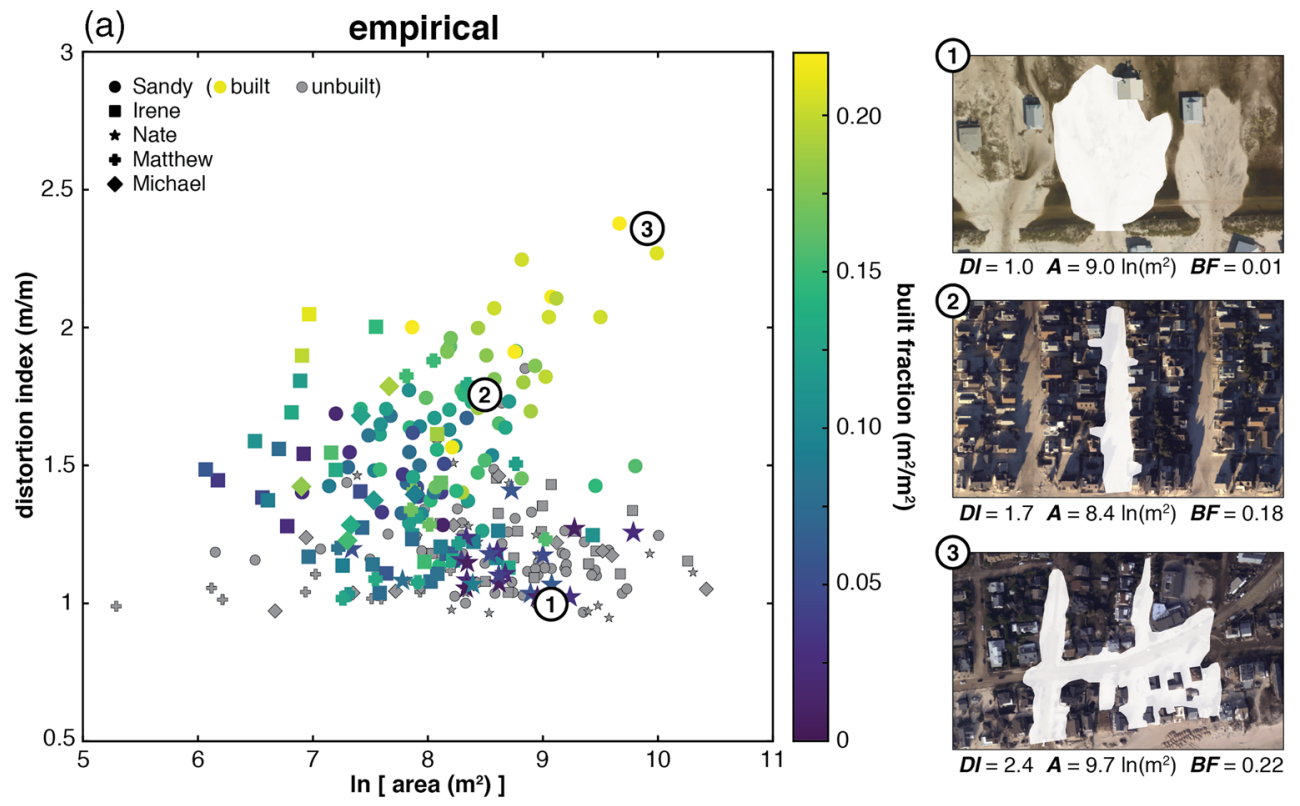

(b)

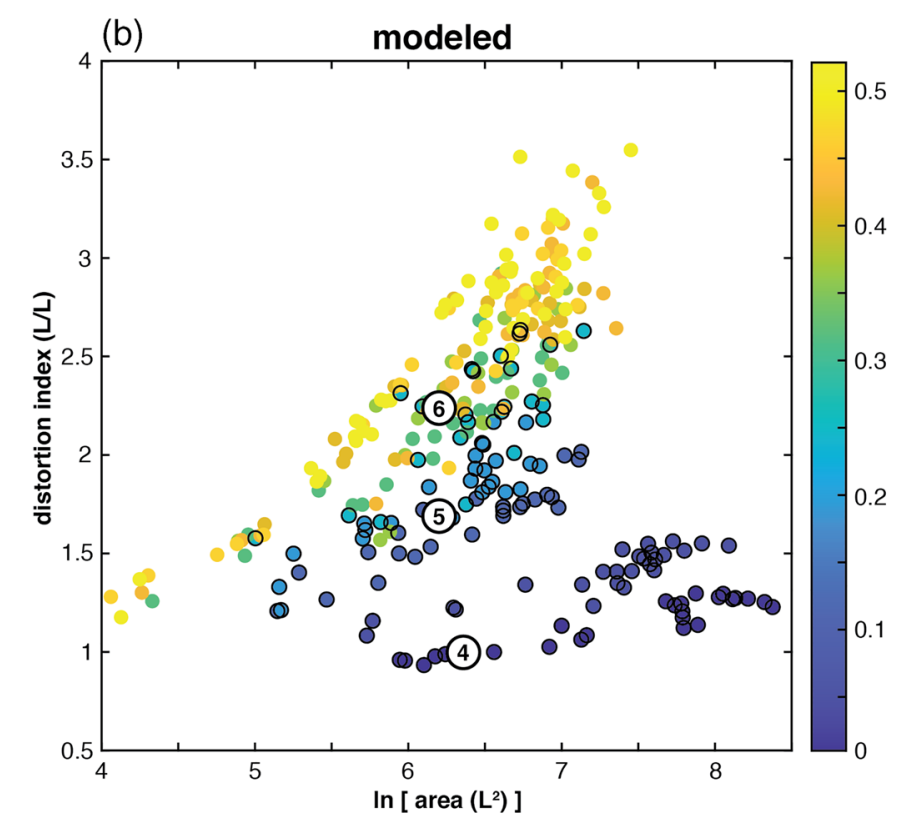

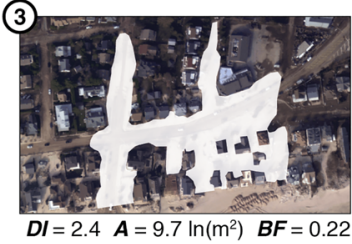
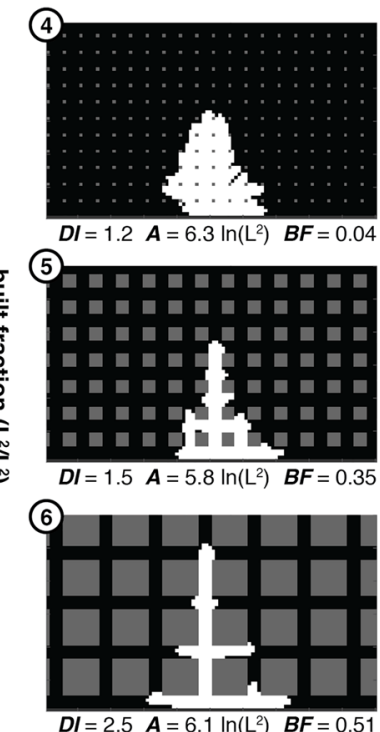

Figure 4. Distortion index (DI) as a measure of washover interaction with the built environment. (a) Distortion index as a function of area, for the empirical data. Color gradient represents built fraction (defined as the total area of building footprints within the convex-hull bounding box around a deposit, divided by the area of that hull). Symbols indicate the hurricane event in which the deposit formed. Gray symbols (with fine black outline) indicate washover measurements from unbuilt settings. Illustrative examples of different deposit morphologies are shown at right: (1) low DI, from Dauphin Island, Alabama, after Hurricane Nate; (2) medium DI, from Seaside Park, New Jersey, after Hurricane Sandy; and (3) high DI, from Bay Head, New Jersey, after Hurricane Sandy. Images from National Oceanic and Atmospheric Administration (NOAA). (b) Distortion index as a function of area, from a simplified numerical model of washover deposition into built environments. Color gradient represents built fraction; circled data points indicate the range of built fractions $(<0.25)$ captured by the empirical data in (a). Illustrative examples from modeled deposits with (4) low, (5) medium, and (6) high DI are shown at right. Additional comparisons are shown in Figures S1, S6, and S7. 

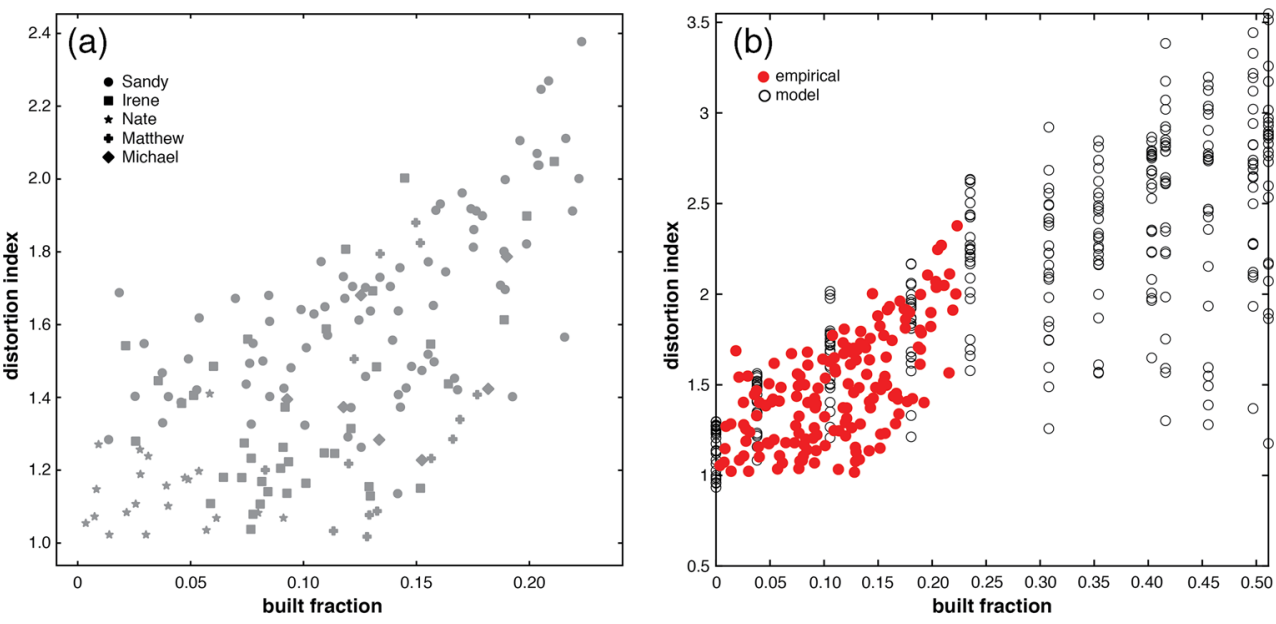

Figure 5. Distortion index (DI) plotted as a function of built fraction (a) for the empirical washover data. Symbols indicate the hurricane event in which the deposit formed. (b) Distortion index plotted as a function of built fraction for empirical (red dots, from panel $A$ ) and modeled results (open circles). The numerical model explores a range of hypothetical built fractions approximately twice that observed in the empirical data.

- express different fabrics (Boeing, 2020). Here, we present results for built fraction (Figure 4a), calculated as the total area of building footprints within a convex-hull bounding box around the deposit divided by the area of that hull (Figure 2a). We also investigated street length, calculated as the total linear length of street within the footprint of a deposit (Figures S4 and S5). However, for washovers that access driveways and spaces between buildings (Figure 2a), a metric derived only from the street network is less descriptive of deposit distortion than a metric that reflects interaction with buildings (Figure S4).

In general, we find a strong positive relationship between built fraction and deposit distortion (Figures 4 and 5; Figure S5). In detail, we also note that for a given area $A$, deposits in the built environment can exhibit a wide range of distortion values that overlap, at the low end $(1<\mathrm{DI}<1.5)$, with measurements from unbuilt settings. More overlap between built and unbuilt DI occurs among deposits with smaller area: even in densely configured built settings, small deposits can form shapes similar to those of small deposits in unbuilt settings if deposition does not interact with enough of the built environment to be distorted. Several examples of overlap between built and unbuilt measurements come from Dauphin Island, Alabama, where deposition by Hurricane Nate extended into a sparsely built environment (mean built fraction $=0.038 \mathrm{~m}^{2}$ / $\mathrm{m}^{2}$ ) (Figure 2b; Figure S1; Table S1). With built fraction so low, deposits by Nate in the built reach of Dauphin Island (mean DI $=1.14$ ) assume almost the same morphology as deposits in the unbuilt reach (mean DI $=1.18$ ). Once the built fraction locally exceeds $\sim 0.15 \mathrm{~m}^{2} / \mathrm{m}^{2}$, deposit distortion in built and unbuilt settings appears to become more mutually distinct, as deposit morphology is forced to conform to available space prescribed by the fabric of the built environment (Figure 4a).

To independently test and expand upon the scaling relationships in the empirical data, we adapted a simplified numerical model of washover deposition (Lazarus \& Armstrong, 2015) to include generic fabrics using built fractions between 0 and 0.5 (twice the range of the empirical observations). For a given built fraction, we ran the model 25 times, with each run generating a single washover deposit from an incision imposed in the fronting dune. Initial dune height and onshore set-up were held constant, but over the 25 trials per built fraction we randomly varied incision location and depth (as a proportion of the fronting dune height) to generate washover deposits of different aerial extent. For floodplain configurations in which the built fraction is null or low, the depth of the initial incision and resulting deposit are positively correlated (Figure S6). As built fraction increases, so does the likelihood that washover at a given site will be blocked, and therefore blunted by a built structure, corroborating a previous example of a built setting reducing washover volume and extent via blocking (Rogers et al., 2015). Randomizing locations of washover initiation means that in some trials washover finds open pathways between built areas, and in others gets blocked by an element of the built environment, collectively producing a wide range of possible washover aerial extents for a given perturbation to the barrier crest and floodplain configuration. The model is not calibrated to real 
length scales, but the patterns of scaling relationships generated by the model closely resemble those in the empirical data (Figure 5; Figure S7). We were able to reproduce a range of deposit areas for a given built fraction, and a similar break in scaling between built and unbuilt settings, particularly evident as deposit area $A$ increases.

\section{Discussion and Implications}

Our empirical and modeled results indicate that the scaling relationships we derive are not storm-dependent. Rather, our findings suggest that in densely built locations, the fabric of the built environment exerts a fundamental control on the morphology of deposits with large areas and, ipso facto, on pathways of overwash flow. Several factors ultimately determine the area of an individual washover deposit in a given storm, including local availability and physical characteristics of sediment; the height, volume, spatial heterogeneity of the fronting dune; local roughness of the terrain being overwashed; proximity to other overwash sites; storm duration; and whether the principal contribution to total water level across the barrier comes from surge or waves (e.g., Engelstad et al., 2018, 2017; Serafin et al., 2017; Wesselman et al., 2018). A storm may be powerful enough to overwhelm the built environment, mooting its role in steering flow and shaping deposition. Also possible is that overwash may flow relatively unobstructed under buildings that are elevated on pilings. However, storm-driven flow and resulting spatial patterns of sediment erosion and deposition beneath elevated houses remain largely unexamined and are not explicitly addressed in this work. Nevertheless, within the limits of a totally destructive event and despite the host of local determinants of deposit morphology, we observe that the fabric of a coastal built environment sets the conditions in which the complex morphodynamics of storm-driven sediment deposition must operate.

Given that washover deposits tend to have a smaller area in built relative to unbuilt settings (Figure 4a), as others have noted by different metrics (Rogers et al., 2015), then control by the built environment on washover size bears fundamentally on the long-term persistence of low-lying coastal barrier environments and their resilience to future hazard impacts. In more immediate terms, without understanding how much hazard-driven sediment fluxes through built environments, or quantifying the anthropogenically modified pathways of that sediment (Lazarus \& Goldstein, 2019; Nordstrom, 2004) - where some portion of which may get plowed back onto the fronting beach, or rebuilt into dunes, or otherwise redirected - then sediment budgets for developed coastlines will remain poorly constrained.

One implication of quantifying scaling relationships for washover deposits in built environments is that management of storm-driven sediment impacts could become less reactionary. Poststorm debris cleanup is expensive, and washover sediment constitutes a type of debris (e.g., EPA, 2019; Federal Emergency Management Agency (FEMA), 2020; Lipton, 2013; Nordstrom, 2004). Greater washover interaction with elements of the local built environment means more work for emergency-response crews. If local managers could predict possible washover patterns (area and volume, especially) based on roads, buildings, and other fixtures of the built environment, they might more efficiently allocate financial resources for mitigating storm impacts or place limits on the maximum built fraction for a given coastal reach. Accurate prediction of washover patterns in the built environment would support the development of more sophisticated risk maps for disaster resiliency in urban planning and emergency management (Berke \& Campanella, 2006). Toward that predictive end, further research is needed to explain the complex relationship, obscured by morphodynamics, between storm intensity and washover size (e.g., area, volume), which remains unclear for built and unbuilt environments alike. Future work should construct scaling relationships between volume and area in built and unbuilt settings. Next-generation catastrophe models of storm-driven damage could soon account for the spatial patterns, and associated economic impacts, of debris cleanup - in addition to the damages from wind, waves, and surge they already consider.

We illustrate control on sediment hazard by built fabric in the context of coastal hurricanes, but the premise of our analysis extends to flow-driven hazards in tsunami, fluvial, debris-flow, and volcanic contexts. Research is beginning to demonstrate links between fabrics and socio-economic metrics as a means of informing spatial planning and urban design (Venerandi et al., 2018). Two key goals of the Sendai Framework for Disaster Risk Reduction (2015-2030) are to "reduce direct economic loss in relation to (gross domestic product)" and to "reduce disaster damage to critical infrastructure and disruption of basic services" (UN General 
Assembly, 2015). Linking the fabric of the built environment and the physical dynamics of environments prone to flow hazards represents a tractable step toward those goals via risk assessment and mitigation - if disaster science and urban sustainability begin to account for true morphodynamics of geomorphic phenomena in built environments.

\section{Data Availability}

Authors empirical measurements and model results are available at doi: 10.6084/m9.figshare.12608828 (link will be made live upon manuscript acceptance). Code for the numerical model is available at https:// github.com/envidynxlab/Model-World.

\section{Acknowledgments}

The authors thank two anonymous reviewers for their constructive comments on the manuscript, and for feedback on the EarthArXiv preprint from the WHOI Mudrakers reading group. They gratefully acknowledge support from The Leverhulme Trust (RPG-2018282, to EDL and EBG), DoD/DARPA (R0011836623/HR001118200064, to EBG), and an Early Career Research Fellowship from the Gulf Research Program of the National Academies of Sciences, Engineering, and Medicine (to EBG). The content is solely the responsibility of the authors and does not necessarily represent the official views of the Gulf Research Program of the National Academies of Sciences, Engineering, and Medicine.

\section{References}

Berke, P. R., \& Campanella, T. J. (2006). Planning for postdisaster resiliency. The Annals of the American Academy of Political and Social Science, 604, 192-207. https://doi.org/10.1177/0002716205285533

Boeing, G. (2017). OSMnx: New methods for acquiring, constructing, analyzing, and visualizing complex street networks. Computers Environment and Urban Systems, 65, 126-139. 10.1016/j.compenvurbsys.2017.05.004

Boeing, G. (2020). A multi-scale analysis of 27,000 urban street networks: every US city, town, urbanized area, and Zillow neighborhood. Environment and Planning B, 47, 590-608. https://doi.org/10.1177/2399808318784595

Bricker, J. D., Gibson, S., Takagi, H., \& Imamura, F. (2015). On the need for larger Manning's roughness coefficients in depth-integrated tsunami inundation models. Coastal Engineering Journal, 57, 1-13. https://doi.org/10.1142/S0578563415500059

Brown, C., Milke, M., \& Seville, E. (2011). Disaster waste management: a review article. Waste Management, 31, 1085-1098. https://doi. org/10.1016/j.wasman.2011.01.027

Bull, W. B. (1977). The alluvial-fan environment. Progress in Physical Geography, 1, 222-270. https://doi.org/10.1177/030913337700100202 Centre for Research on the Epidemiology of Disasters (CRED). (2019). EM-DAT: The emergency events database (Université Catholique de Louvain [UCL]). Brussels, BE. Centre for Research on the Epidemiology of Disasters [CRED]. Retrieved from http://www.emdat.be (accessed July 2020).

Del Ventisette, C., Garfagnoli, F., Ciampalini, A., Battistini, A., Gigli, G., Moretti, S., \& Casagli, N. (2012). An integrated approach to the study of catastrophic debris-flows: geological hazard and human influence. Natural Hazards and Earth System Sciences, 12, $2907-2922$. https://doi.org/10.5194/nhess-12-2907-2012

Dodds, P. S., \& Rothman, D. H. (2000). Scaling, universality, and geomorphology. Annual Review of Earth and Planetary Sciences, 28, 571-610. https://doi.org/10.1146/annurev.earth.28.1.571

Donnelly, C., Kraus, N., \& Larson, M. (2006). State of knowledge on measurement and modeling of coastal overwash. Journal of Coastal Research, 22, 965-991. https://doi.org/10.2112/04-0431.1

Doronzo, D. M., \& Dellino, P. (2011). Interaction between pyroclastic density currents and buildings: numerical simulation and first experiments. Earth and Planetary Science Letters, 310, 286-292.

Ellis, E. C., \& Ramankutty, N. (2008). Putting people in the map: anthropogenic biomes of the world. Frontiers in Ecology and the Environment, 6, 439-447. https://doi.org/10.1016/j.epsl.2011.08.017

Engelstad, A., Ruessink, B. G., Hoekstra, P., \& van der Vegt, M. (2018). Sand suspension and transport during inundation of a Dutch barrier island. Journal of Geophysical Research: Earth Surface, 123, 3292-3307. https://doi.org/10.1029/2018JF004736

Engelstad, A., Ruessink, B. G., Wesselman, D., Hoekstra, P., Oost, A., \& van der Vegt, M. (2017). Observations of waves and currents during barrier island inundation. Journal of Geophysical Research: Oceans, 122, 3152-3169. https://doi.org/10.1002/2016JC012545

Environmental Protection Agency (EPA). (2019). Planning for natural disaster debris, EPA 530-F-19-003 (pp. D1-D19). Environmental Protection Agency. Retrieved from https:/www.epa.gov/sites/production/files/2019-04/documents/final_pndd_guidance_0.pdf

Federal Emergency Management Agency (FEMA). (2020). Public assistance program and policy guide (Version 4), FP 104-009-2 (p. 276). FEMA.

FitzGerald, D. M., Fenster, M. S., Argow, B. A., \& Buynevich, I. V. (2008). Coastal impacts due to sea-level rise. Annual Review of Earth and Planetary Sciences, 36, 601-647. https://doi.org/10.1146/annurev.earth.35.031306.140139

Foley, J. A., DeFries, R., Asner, G. P., Barford, C., Bonan, G., Carpenter, S. R., et al. (2005). Global consequences of land use. Science, 309, 570-574. https://doi.org/10.1126/science.1111772

Grinsted, A., Ditlevsen, P., \& Christensen, J. H. (2019). Normalized US hurricane damage estimates using area of total destruction, 19002018. Proceedings of the National Academy of Sciences, 116, 23942-23946. https://doi.org/10.1073/pnas.1912277116

Gurioli, L., Pareschi, M. T., Zanella, E., Lanza, R., Deluca, E., \& Bisson, M. (2005). Interaction of pyroclastic density currents with human settlements: Evidence from ancient Pompeii. Geology, 33, 441-444. https://doi.org/10.1130/G21294.1

Gurioli, L., Zanella, E., Pareschi, M. T., \& Lanza, R. (2007). Influences of urban fabric on pyroclastic density currents at Pompeii (Italy): 1. Flow direction and deposition. Journal of Geophysical Research, 112, B05213. https://doi.org/10.1029/2006JB004444

Hall, M. J., \& Halsey, S. D. (1991). Comparison of overwash penetration from Hurricane Hugo and pre-storm erosion rates for Myrtle Beach and North Myrtle Beach, South Carolina, U.S.A. Journal of Coastal Research, 8, 229-235.

Halpern, B. S., Frazier, M., Potapenko, J., Casey, K. S., Koenig, K., Longo, C., et al. (2015). Spatial and temporal changes in cumulative human impacts on the world's ocean. Nature Communications, 6, 7615. https://doi.org/10.1038/ncomms8615

Hudock, J. W., Flaig, P. P., \& Wood, L. J. (2014). Washover fans: a modern geomorphologic analysis and proposed classification scheme to improve reservoir models. Journal of Sedimentary Research, 84, 854-865. https://doi.org/10.2110/jsr.2014.64

Kossin, J. P., Knapp, K. R., Olander, T. L., \& Velden, C. S. (2020). Global increase in major tropical cyclone exceedance probability over the past four decades. Proceedings of the National Academy of Sciences of the United States of America, 117, 11975-11980. https://doi. org/10.1073/pnas.1920849117

Lazarus, E. D. (2016). Scaling laws for coastal overwash morphology. Geophysical Research Letters, 43, 113-119. https://doi.org/10.1002/2016GL071213 
Lazarus, E. D., \& Armstrong, S. (2015). Self-organized pattern formation in coastal barrier washover deposits. Geology, 43, 363-366. https:// doi.org/10.1130/G36329.1

Lazarus, E. D., Davenport, K. L., \& Matias, A. (2020). Dynamic allometry in coastal overwash morphology. Earth Surface Dynamics, 8 , 37-50. https://doi.org/10.5194/esurf-8-37-2020

Lazarus, E. D., \& Goldstein, E. B. (2019). Is there a bulldozer in your model? Journal of Geophysical Research: Earth Surface, 124, 696-699. https://doi.org/10.1029/2018JF004957

Leatherman, S. P., \& Zaremba, R. E. (1987). Overwash and aeolian processes on a U.S. northeast coast barrier. Sedimentary Geology, 52, 183-206.

Lipton, E. (2013). Cost of storm-debris removal in city is at least twice the U.S. average. New York Times. Retrieved from https://www.nytimes.com/2013/04/25/nyregion/debris-removal-from-hurricane-sandy-is-more-costly-than-average.html

Masselink, G., \& van Heteren, S. (2014). Response of wave-dominated and mixed-energy barriers to storms. Marine Geology, 352, 321-347. https://doi.org/10.1016/j.margeo.2013.11.004

Matias, A., Vila-Concejo, A., Ferreira, O., Morris, B., \& Dias, J. A. (2009). Sediment dynamics of barriers with frequent overwash. Journal of Coastal Research, 25, 768-780. https://doi.org/10.2112/08-1032.1

Millard, C., Hajek, E., \& Edmonds, D. A. (2017). Evaluating controls on crevasse-splay size: Implications for floodplain-basin filling. Journal of Sedimentary Research, 87, 722-739. https://doi.org/10.2110/jsr.2017.40

Morton, R. A., \& Paine, J. G. (1985). Beach and vegetation-line changes at Galveston Island, Texas: Erosion, deposition and recovery from Hurricane Alicia. Geological Circular (p. 39). Bureau of Economic Geology, University of Texas at Austin.

Morton, R. A., \& Sallenger, A. H. (2003). Morphological impacts of extreme storms on sandy beaches and barriers. Journal of Coastal Research, 19, 560-573. https://doi.org/10.1130/B31221.1

Moscardelli, L., \& Wood, L. (2016). Morphometry of mass-transport deposits as a predictive tool. Geological Society of America Bulletin, 128, 47-80. https://doi.org/10.1130/B31221.1

National Geodetic Survey. (2020). Emergency response imagery. NOAA. Retrieved from https://storms.ngs.noaa.go

National Oceanic and Atmospheric Administration [NOAA]. (2013). reportNational coastal population report: State of the coast. NOAA

Nelson, S. A., \& Leclair, S. F. (2006). Katrina's unique splay deposits in a New Orleans neighbourhood. Geological Society of America Today, 16, 4-10. https://doi.org/10.1130/GSAT01609A.1

Nordstrom, K. F. (2004). Beaches and dunes of developed coasts (p. 347). Cambridge University Press.

Overbeck, J. R., Long, J. W., Stockdon, H. F., \& Birchler, J. J. (2015). Enhancing evaluation of post-storm morphologic response using aerial orthoimagery from Hurricane Sandy. In P. Wang, \& J. D. Rosati (Eds.), Coastal sediments 2015 (p. 14). Miami, FL: World Scientific.

Papathoma-Köhle, M., Gems, B., Sturm, M., \& Fuchs, S. (2017). Matrices, curves and indicators: A review of approaches to assess physical vulnerability to debris flows. Earth-Science Reviews, 171, 272-288. https://doi.org/10.1016/j.earscirev.2017.06.007

Park, H., Cox, D. T., Lynett, P. J., Wiebe, D. M., \& Shin, S. (2013). Tsunami inundation modeling in constructed environments: A physical and numerical comparison of free-surface elevation, velocity, and momentum flux. Coastal Engineering, 79, 9-21. https://doi. org/10.1016/j.coastaleng

Periathamby, A., Hamid, F. S., \& Sakai, S. (2012). Disaster waste management challenges. Waste Management \& Research, 30, 113-114. https://doi.org/10.1177/0734242X11434630

Price, W. A. (1947). Equilibrium of form and forces in tidal basins of coast of Texas and Louisiana. AAPG Bulletin, 31(9), 1619-1663.

Rogers, L. J., Moore, L. J., Goldstein, E. B., Hein, C. J., Lorenzo-Trueba, J., \& Ashton, A. D. (2015). Anthropogenic controls on overwash deposition: Evidence and consequences. Journal of Geophysical Research: Earth Surface, 120, 2609-2624. https://doi. org/10.1002/2015JF003634

Sallenger, J. (2000). Storm impact scale for barrier islands. Journal of Coastal Research, 16, 890-895.

Serafin, K. A., Ruggiero, P., \& Stockdon, H. F. (2017). The relative contribution of waves, tides, and nontidal residuals to extreme total water levels on U.S. West Coast sandy beaches. Geophysical Research Letters, 44, 1839-1847. https://doi.org/10.1002/2016GL071020

Shaw, J., You, Y., Mohrig, D., \& Kocurek, G. (2015). Tracking hurricane-generated storm surge with washover fan stratigraphy. Geology, 43, 127-130. https://doi.org/10.1130/G36460.1

Sherwood, C. R., Warrick, J. A., Hill, A. D., Ritchie, A. C., Andrews, B. D., \& Plant, N. G. (2018). Rapid, remote assessment of Hurricane Matthew impacts using four-dimensional structure-from-motion photogrammetry. Journal of Coastal Research, 34, 1303-1316. https:// doi.org/10.2112/JCOASTRES-D-18-00016.1

Smallegan, S. M., \& Irish, J. L. (2017). Barrier island morphological change by bay-side storm surge. Journal of Waterway, Port, Coastal, and Ocean Engineering, 143, 04017025. https://doi.org/10.1061/(ASCE)WW.1943-5460.0000413

UN General Assembly. (2015). The Sendai Framework for disaster risk reduction 2015-2030 (pp. 1-24). UN General Assembly. Retrieved from http://www.unisdr.org/files/43291_sendaiframeworkfordrren.pdf

USGS. (2005). Pre- and post-storm 3D topography: Dauphin Island. U.S. Geological Survey. Retrieved from https://coastal.er.usgs.gov/ hurricanes/katrina/lidar/dauphin-island.html

Venerandi, A., Quattrone, G., \& Capra, L. (2018). A scalable method to quantify the relationship between urban form and socio-economic indexes. EPJ Data Science, 7, 1-21. https://doi.org/10.1140/epjds/s13688-018-0132-1

Venter, O., Sanderson, E. W., Magrach, A., Allan, J. R., Beher, J., Jones, K. R., et al. (2016). Sixteen years of change in the global terrestrial human footprint and implications for biodiversity conservation. Nature Communications, 7, 12558. https://doi.org/10.1038/ ncomms 12558

Vitousek, P. M., Mooney, H. A., Lubchenco, J., \& Melillo, J. M. (1997). Human domination of the Earth's ecosystems. Science, 277, 494-499. https://doi.org/10.1007/978-0-387-73412-5_1

Wesselman, D., de Winter, R., Engelstad, A., McCall, R., van Dongeren, A., Hoekstra, P., et al. (2018). The effect of tides and storms on the sediment transport across a Dutch barrier island. Earth Surface Processes and Landforms, 43, 579-592. https://doi.org/10.1002/esp.4235

Zanella, E., Gurioli, L., Pareschi, M. T., \& Lanza, R. (2007). Influences of urban fabric on pyroclastic density currents at Pompeii(Italy): 2. Temperature of the deposits and hazard implications. Journal of Geophysical Research, 112, B05214. https://doi.org/10.1029/2006JB004775 